\title{
Is there a world beyond academic geography? A reply to Ben Derudder
}

\author{
Bruno Meeus, Nick Schuermans and Filip De Maesschalck \\ Department of Earth and Environmental Sciences \\ Katholieke Universiteit Leuven \\ Celestijnenlaan $200 \mathrm{E}$ \\ 3001 Heverlee \\ Belgium \\ Email: Bruno.Meeus@ees.kuleuven.be
}

In a recent observation, Ben Derudder (2011) develops two thought-provoking points about the increasing dominance of Web of Science journals in the publication practices of human geographers and the way in which it has been criticized. Derudder's first point relates to the underestimated diversity of the journals indexed by the Web of Science. While he acknowledges that the "database is definitely geographically biased" and that "there is indeed a danger of research being disciplined in unwanted directions" (Derudder 2011, 2), he also underlines that "there has been a tendency towards a more diverse and multi-tiered coverage". He argues, for example, that researchers working with feminist or critical theories can publish in journals such as Gender, Place \& Culture and Antipode and that the dominance of English and Anglo-American publications is being challenged by the inclusion of journals from Sweden, Germany, Chile and South Africa. As a second point, Derudder condemns the tendency to portray academic geographers as innocent victims of external demands imposed upon them. In his view, the increasing importance of the Web of Science cannot be blamed on 'research agencies', 'benchmarking committees' and 'neo-liberal capitalism' alone. As long as we send our articles to Web of Science journals, Derudder advocates, our complicity cannot be disguised.

Although we agree with most of Derudder's arguments, we are pleased that we have been invited to write a reply. Our main problem with Derudder's observation is that he cites our article (Schuermans et al. 2010) six times, but that he misses our central point. By quoting our contention that a "one-sided focus on Web of Science publications [...] might lead to the neglect of some geographical subdisciplines" (Schuermans et al. 2010, 423 in Derudder $2011,1)$ and that "the changing publication practices of Belgian geographers cannot be understood without referring to the external demands facing them' (Schuermans et al. 2010, 422 in Derudder 2011, 2, his emphasis), Derudder neglects our central claim. In fact, we did not want to argue that the tendency to reduce a CV to the total number of Web of Science publications would kill the diversity and the quality of academic geography. In the first place, we were worried about the role of academic geography in public debates. By way of example, it can be stressed that the abstract of our original article mentioned already that "we applaud the tendency to publish in English and in Web of Science journals because it increases the academic rigour of scholarly research", but that "we are afraid that it hampers the role of academic geography in geography education and society as a whole" (Schuermans et al. 2010, 417). We also finished our article by throwing up the question whether we should "only care about the impact factors of our Web of Science articles or also about their impact on society at large" (Schuermane et al. 2010, 422, our emphasis).

Because Derudder does not look beyond the academic world, we would like to raise three short points. At first, we want to underscore that we agree with him about the diversity of theoretical approaches and research paradigms in the Web of Science. Over the last ten years, the pluri-paradigmatic character of human geography is, indeed, increasingly being reflected in the journals indexed by the database. In the same way, we consent that it is difficult to speak of the 'Web of Science' as the Anglophone 'heartland' of human geography now that geographical journals from a wider range of countries are being included in the database. Our fears about the neglect of some geographical subdisciplines, research topics 
and research methodologies were not inspired by worries about the prospect of academic geography, however, but by concerns about the future relations between academic geographers and the wider society in which they work. If human geographers are increasingly forced to conduct research that could be published in the Web of Science, there is a risk that there is less time or money for other research that is also interesting for teachers, policy makers and other citizens. In our original article, we referred, for example, to the fact that general reviews of the Belgian political landscape are not written anymore because the research behind it is not specialised and fundamental enough to be easily converted into Web of Science articles (cfr. Walgrave et al. 2008, 187-8).

Our second point adds up to this. Even though Derudder mentions that the Journal of Latin American Urban and Regional Studies (EURE) accepts papers in Spanish and Portuguese, it has to be acknowledged that more than 95 per cent of the publications in the Web of Science are still in English. In our view, this is not a problem for academic geography as such. In fact, we accept that a lingua franca is a necessity in the creation of a global academic community. We also recognize, however, that English is not the language in which Danish, Estonian or Belgian academics interact with policy makers, teachers, action groups, planners and civil society in their countries. While Derudder $(2011,1)$ limits the problems associated with the hegemonic position of the English language to the "creative destruction of papers" and the "cold hard fact that language editing costs time and/or money" (cfr. Aalbers 2004), we believe that it is more essential that the use of English and academic jargon drives a wedge between academic geographers and the world beyond the university. In this context, it is not only language that is crucial, but also availability of publications. In our original article, we did not only explain the popularity of Brussels Studies by referring to the fact that it is a completely trilingual journal (French, Dutch and English), but also by pointing to the reality that it is freely available on the internet. If we rarely write for such local journals, and if research assessment exercises do not encourage us to do so, we might lose the connection with the hundreds of non-specialised readers that download these publications nowadays.

This brings us to our third point; that of complicity. While we agree with Derudder that critics have too often poorly specified the actors involved in the expansion of the Web of Science, we also think that he underestimates the power of the 'external demands' imposed upon researchers and journal editors. To reveal the whole picture, we should have attention for the way in which research institutes are financed and influenced by national and regional research policies and for the strategies that the large publishing houses deploy to enlarge their markets. In our view, the main problem is, however, not our complicity in the increased dominance of Web of Science journals. Even if we accept that we have too simply adapted to the neo-liberal strategies of international publishers and the demands of the changing meritocratic landscape, we fear that we are becoming complicit in something much more important. In-stead of focusing on our complicity in changing publication practices, we believe that it is our potential complicity in the divide between academic geography and the wider society that should be our first concern.

Obviously, this divide cannot be overcome by writing articles in local journals alone. However, because we are convinced that such articles do have an impact, we endorse Aalbers and Rossi's (2007) plea for 'multi-tier spaces of academic publishing'. By continuing to write different articles for different journals in different languages, Danish, Estonian or Belgian human geographers will be able to keep on serving different audiences. By way of example, we can refer to our own paper. We did not only submit it to Area to develop our academic careers - as Derudder $(2011,2)$ suggests - but also to increase the chance that human geographers outside of Belgium would pick up our findings and discuss them. While Area is an excellent outlet to fuel a debate about the increasing role of the Web of Science among fellow academics all over the world, it is not the best place to start up a discussion in Belgium with people outside the universities. By asking which civil servants are going to pay to access our articles, by wondering which policy makers will struggle with our academic English and by questioning which public sector employees are going to do the effort to translate our conclusions into policy recommendations, it becomes clear that we - and the systems 
designed to evaluate us - have to value more than our bibliographic records in the Web of Science alone.

\section{References}

Aalbers M B 2004 Creative destruction through the Anglo-American hegemony: a nonAnglo-American view on publications, referees and language Area 36 319-22

Aalbers M B and Rossi U 2007 A coming community: young geographers coping with multitier spaces of academic publishing across Europe Social \& Cultural Geography 8 283-302

Derudder B 2011 Some reflections on the 'problematic' dominance of 'Web of Science' journals in academic human geography Area 431 doi: 10.1111/j.1475-4762.2010.00969.x

Schuermans N Meeus B and De Maesschalck F 2010 Is there a World beyond the Web of Science? Publication practices outside the heartland of academic geography Area 424 417424

Walgrave S, Oversloot $\mathbf{H}$ and Stouthuysen $\mathbf{P} 2008$ Schrijven is blijven of toch maar publish or perish? Res Publica 50 179-92

Full reference Meeus, B., Schuermans, N., De Maesschalck, F. (2010) Is there a world beyond academic geography? A reply to Ben Derudder, Area, 43, 1, p. 113-114.

Disclaimer The definitive version of this article is available at www.blackwell-synergy.com http://onlinelibrary.wiley.com/doi/10.1111/j.1475-4762.2010.00987.x/pdf 